UDC 504.064:504.3

Taras V. Trysnyuk, $\mathrm{PhD}$

ORCID ID: 0000-0002-3672-8242,e-mail: taras24t@gmail.com

Institute of Telecommunications and Global Information Space of NASU, Kyiv, Ukraine

\title{
MOBILE ENVIRONMENTAL MONITORING SYSTEM OF THE DNIESTER: MODELING OF TECHNICAL SYSTEM OF HYDRO RESOURCES AND EXTREME FLOODS
}

\begin{abstract}
The mobile environmental monitoring system is aimed at increasing the processing speed of measurement analyzes and increasing the scale of the study. The algorithm of analysis and modeling of extreme floods includes: construction of a series of hydrographic maps of the largest floods and graphs of characteristic water levels, assessment of the peculiarities of floods, formation of a database on channel morphometry and the state of flood objects. An important role is given to the assessment and forecast of the state of the Dniester and anthropogenic impacts on it in connection with such indicators as morbidity and control of pollution caused by flooding. Man-caused ecological safety of use of hydro resources and hydroecosystems in general should be based on the hydroecosystem concept of balanced nature use. GIS technologies (ArcView GIS 3.2a) were used to directly implement the tasks of estimating the time of penetration of pollutants into groundwater. The evaluation of the protective properties of the rocks of the aeration zone was performed by creating a spatial model to determine the relationship between objects using the module Georgesessig ArcGIS. Survey materials allow you to create 3D terrain models with an accuracy of 15-20 cm and aerial mosaics at a scale of 1: $1000-1: 5000$.
\end{abstract}

Key words: mobile ecological monitoring; modeling of extreme floods; anthropogenic impact; digital relief model; hydroecosystem

\section{Т.В. Триснюк}

Інститут телекомунікацій і глобального інформаційного простору НАН України, м. Київ, Україна

\section{СИСТЕМА МОБІЛЬНОГО ЕКОЛОГІЧНОГО МОНІТОРИНГУ ДНІСТРА: МОДЕЛЮВАННЯ ТЕХНІЧНОЇ СИСТЕМИ ГУДРОРЕСУРСІВ ТА ЕКСТРЕМАЛЬНИХ ПАВОДКІВ}

\begin{abstract}
Анотація. Система мобільного екологічного моніторингу спрямована на збільшення швидкості обробки аналізів вимірювання $і$ збільшення масштабів дослідження. Алгоритм аналізу та моделювання екстремальних паводків включає: побудову серії гідрографічних карт найбільших паводків і графіків характерних рівнів води, оиінку особливостей проходження паводків, формування бази даних про морфометрію русла і стан протипаводкових об'єктів. Особлива увага приділяється оиінці і прогнозу стану Дністра й антропогенних впливів на нього у зв'язку з такими показниками, як захворюваність населення, та контролю за забрудненнями, що утворилися 8 результаті підтоплень. Техногенна екологічна безпека використання гідроресурсів $i$ гідроекосистем $в$ иілому повинна базуватись на гідроекосистемній кониепиії збалансованого природокористування. Для безпосередньої реалізації завдань з оичнки часу проникнення забруднюючих
\end{abstract}


речовин в трунтові води використано ГIC-технології (ArcView GIS 3.2a). Оиінку захисних властивостей порід зони аераиії було виконано шляхом створення просторової моделі для визначення взаємозв'язку між об'єктами за допомогою модуля Geоргосеssing ArcGIS. Матеріали знімання дають змогу створити 3D моделі рельєфу із точністю 15-20 см та аерофотомозаїку масштабу 1: 1000 - 1: 5000.

Ключові слова: мобільний екологічний моніторинг; моделювання екстремальних паводків; антропогенний вплив; ичифрова модель рельєфу; гідроекосистема

DOI: 10.32347/2411-4049.2021.2.121-128

\section{Постановка проблеми}

Алгоритм аналізу та моделювання екстремальних паводків включає: побудову серії гідрографів найбільших паводків і графіків характерних рівнів води, оцінку особливостей проходження паводків, формування бази даних про морфометрію русла і стан протипаводкових об'єктів, створення гідрологічно коректної цифрової моделі рельєфу, оглядової ГІС-моделі, яка визначає межі зон ризику підтоплення при заданих рівнях води, побудову детальніших (великомасштабних) моделей ризику затоплення паводками для ключових ділянок річкової долини.

\section{Мета дослідження}

Внаслідок значного техногенного впливу на геологічне середовище спостерігаються комплексні зміни геохімічних, гідрогеологічних, інженерногеологічних умов, які в ряді регіонів призводять до стійкого погіршення природної обстановки і набули транскордонного характеру. Суттєвих змін зазнають гідрохімічні та гідродинамічні показники поверхневих та підземних вод. Одними з головних актуальних питань оцінки еколого-геологічного стану ГС є вивчення стану підземних вод і проблем, що з цим пов'язані. Соціальний компонент моніторингу органічно пов'язаний з усіма іншими компонентами і у комплексі спрямований на вирішення наступних завдань: розробка програм спостереження за станом навколишнього природного середовища визначеної акваторії Дністра; організація спостережень і проведення вимірів показників об'єктів екологічного моніторингу; збір і обробка результатів спостережень; гармонізація банків і баз екологічної інформації з міжнародними екологоінформаційними системами. Особлива увага приділяється оцінці і прогнозу стану Дністра й антропогенних впливів на нього у зв'язку 3 такими показниками, як здоров'я населення, та контролю за забрудненнями, що утворилися в результаті підтоплень.

\section{Організація та результати дослідження}

Природно-техногенна гідроекосистема керується за рахунок запасу та обміну інформацією, яка надходить від екологічного моніторингу. Стосовно саме таких систем може бути сформульований принцип техногенної екологічної безпеки - стан, при якому забезпечується стійка взаємодія людини і природи. На нашу думку, техногенна екологічна безпека використання гідроресурсів і гідроекосистем в цілому повинна базуватись на гідроекосистемній концепції збалансованого природокористування, а саме: 
1. довкіллю притаманна гідроекосистемна ієрархія;

2. гідроекосистеми є частиною гідроекологічного середовища;

3. гідроекосистеми характеризуються "організаційністю";

4. в межах гідроекосистем нерозривно взаємопов'язані природні умови та господарська діяльність;

5. гідроекосистеми - оптимальні територіальні одиниці моніторингу природного середовища;

6. використання картографічного та імітаційного математичного моделювання гідроекосистем - основа прогнозування та оптимізації стану гідроекосистем.

Серед загального складного комплексу робіт великого значення набуває оцінка захисних властивостей зони аерації. Зона аерації служить природним захистом підземних вод від забруднення у природних і екстремальних умовах. Iї характеристики визначають час проникнення забруднення у перший від поверхні водоносний горизонт, у іï межах здійснюються процеси сорбції та іонний обмін. Для умов України, де більша частина сільського населення (близько 70\%) використовує води першого від поверхні водоносного горизонту, що зазнав техногенного забруднення нітратами, сульфатами, хлоридами, важкими металами, органічними сполуками тощо, дослідження 3 оцінки захисних властивостей порід зони аерації i прогнозування потрапляння забруднення у грунтові води набуває особливо важливого значення [1].

Основними природними показниками, на яких грунтуються оцінки 3 визначення часу надходження забруднюючих речовин з поверхні землі до грунтових вод, стали ії потужність і літологічний склад порід зони аерації.

У структурі соціального складника екологічного моніторингу басейну Дністра ми виділяємо тематичні і територіальні підсистеми. Тематичні підсистеми здійснюють спостереження і контроль за станом окремих об'єктів, що підлягають екологічному моніторингу. Кожна тематична система складається 3 однієї чи декількох систем спостереження і контролю, об'єднаних за принципом “спільності об’єкта” моніторингу. Ці підсистеми стежать за екологічним станом об'єктів навколишнього природного середовища; за екологічною безпекою людей у залежності від стану компонентів системи; за станом i якістю природних ресурсів, що використовуються у конкретних видах діяльності; за станом джерел антропогенного впливу на екосистему Дністра. Державний моніторинг водних об'єктів, запасів поверхневих і підземних вод здійснюють відповідні державні органи. Територіальні підсистеми екологічного контролю басейну Дністра створюються відповідно до пунктів забору проб. Побудова таких підсистем реалізується через ієрархічний принцип i, коли екологічна обстановка цього вимагає, забезпечує прицільне інформування населення у місцях виникнення екологічної напруженості. Цей підхід виправдовує себе, оскільки основні екологічні показники в усьому басейні Дністра не залишаються однаковими та не розподіляються рівномірно. 3 метою створення єдиного науковометодичного підходу до комплексного спостереження стану Дністра, з огляду на сформовану напружену екологічну обстановку, розпочата робота 3 відпрацьовування i впровадження систем екологічного моніторингу у практику керування природоохоронною діяльністю й екологічною безпекою. 3 огляду на застосування можливостей ГІС при регіональних картографічних побудовах та подальшу систему оцінок захищеності грунтових вод, для 
виконання даного виду робіт були задіяні попередньо створені електронні карти потужності зони аерації та будови літологічного складу іiі порід масштабу 1: 100000 . Кожна із залучених для цих побудов вихідних електронних карт була піддана попередній обробці, яка полягала в генералізації виділених підрозділів [2].

Для безпосередньої реалізації завдань 3 оцінки часу проникнення забруднюючих речовин в грунтові води використані ГІС-технології (ArcView GIS 3.2a). Оцінку захисних властивостей порід зони аерації було виконано шляхом створення просторової моделі для визначення взаємозв'язку між об'єктами за допомогою модуля Geоргосеssing ArcGIS. Для створення моделі використовувався метод векторного накладання шарів, який дозволяє автоматично визначити області перетину об'єктів та територій, що зіставляються. В результаті створюється новий набір даних, в якому кожній результуючій області присвоєні атрибути обох вихідних. Для розрахунку часу проникнення були використані інформаційний шар літологічних різновидів зони аерації та шар інформаційних потужностей зони аерації. Для кожного виділеного таксону, залежно від будови його розрізу, обчислення виконувалося за відповідними формулами. В залежності від розрахункового часу можливого проникнення виділяємо 5 його градацій: $<50$ діб; 50-250 діб; 250-1000 діб; 1000-3000 діб; > 3000 діб. Хоча таке районування певною мірою умовне i схематичне, воно відображає загальну тенденцію можливого проникнення забруднюючих речовин у грунтові води. До того ж районування базується на об'єктивних даних щодо проаналізованої значної кількості достовірної інформації про літологічний склад, фільтраційні особливості і потужності зони аерації і цілком прийнятне при здійсненні загальних регіональних оцінок [3].

При цьому засоби вимірювання, використовувані природокористувачами, повинні відповідати вимогам стандартизації і метрології. Нами зроблено спроби встановлення контактів 3 підприємствами, що є користувачами вод Дністра, i поширення на цих підприємствах інформації про стан довкілля та стан вод Дністра. Це є один 3 важливих аспектів формування громадської думки про необхідність зменшення техногенного навантаження на акваторію Дністра. Основою методики збору та систематизації інформації $\epsilon$ обробка картографічного матеріалу шляхом векторизації [4]. При складанні бази даних враховувались характерні особливості природних об'єктів та їх взаємодія. Ще однією методикою отримання інформації, що використовувалася нами при побудові моделей басейнової системи, було опрацювання даних дистанційного зондування Землі, яке дозволило скласти карту землекористування досліджуваного басейну. Враховуючи важливе значення даних дистанційного зондування для визначення ступеня антропогенного впливу на довкілля, нами були використані різночасові космознімки таких джерел, як „СІЧ-2", LANDSAT.

Можливості традиційних методів досліджень причинно-наслідкових закономірностей формування якості поверхневих вод суттєво розширюються при використанні матеріалів дистанційного зондування водних об'єктів та їх поверхневих водозборів. Сучасні технічні засоби дистанційного зондування дозволяють отримати достатньо різноманітну інформацію про властивості земної поверхні у видимій (0,3-0,8 мкм), ближній (1,8-5,3 мкм) і дальній (7-14 мкм) ІЧ-областях спектра, а також в діапазоні НВЧ (3-100 см). Спеціальними методами обробки різних видів цієї інформації вивчаються 
закономірності просторово-часових розподілів водних мас, які відрізняються вмістом розчинених або зважених речовин природного та антропогенного походження [5].

Вся кадастрова інформація опрацьована за допомогою геоінформаційних технологій у програмному середовищі ArcGIS. Географічною основою для баз геоданих послужила цифрова карта областей Західної України масштабу 1: 200000 із вказаними населеними пунктами, нанесеними залізницями, автодорогами, водотоками та іншими природними і техногенними об'єктами. Картографічна основа узгоджена із космознімками LANDSAT 5 із роздільною здатністю 10 i 30 м відповідно. Це дозволяло точніше дешифрувати досліджувані об'єкти та наносити їх на карту. Новим прогресивним методом вважають також повітряне лазерне сканування промислових об'єктів з одночасною прив'язкою через GPS-приймач до географічних координат. Матеріали знімання дають змогу створити 3D моделі рельєфу із точністю 15-20 см та аерофотомозаїку масштабу 1: 1000 - 1: 5000 , отримати інформацію про конструкційні й експлуатаційні параметри інженерних споруд і будівель, розрахувати технічні параметри гірничих об'єктів (кар'єрів, відвалів, відстійників тощо) за їхніми тривимірними моделями [6].

Кінцевою метою моделювання природно-технічної системи $є$ управління технологічними й екологічними процесами в інтересах іiі стабілізації або розвитку. Відповідно до цієї мети можна виділити три етапи моделювання: інформаційне забезпечення, імітаційне моделювання, управлінське моделювання [7].

Перший етап моделювання пов'язаний з формуванням банку інформації за трьома напрямками:

1. Збір та аналіз результатів натурних спостережень, інженерних вишукувань, вивчення архівних матеріалів з метою накопичення первинної інформації;

2. Використання традиційних моделей 3 визначення розрахункової інформації, наприклад моделі швидкостей течії, стратифікації у водоймах;

3. Генерування інформації, якої недостатньо як вихідної, наприклад, за аналогічними басейновими гідроекосистемами або природними умовами. Метод аналогій доцільно використовувати для прогнозу природних передумов і екологічних наслідків антропогенного навантаження (наприклад, розташування МГЕС) в межах басейнових екосистем досліджуваного регіону. Другий етап моделювання ставить собі за мету розробку імітаційних моделей для формалізації взаємодії техногенних і екологічних процесів. Найбільш загальною формою моделі природно-техногенного процесу $є$ багатофакторні моделі у вигляді регресійних залежностей. Імітаційні моделі є вихідними для визначення прогнозних ситуацій, які оцінюють вірогідні екологічні ситуації. Така оцінка проводиться на третьому етапі модельних досліджень. Залежно від результату, що прогнозується, приймаються рішення щодо управління системи на основі багатокритеріального аналізу (3-й етап). Виконані роботи 3 оцінки захисних властивостей порід зони аерації в цілому дозволяють диференціювати досліджувану територію за умовами захищеності грунтових вод від забруднення. Даний інформаційний матеріал в сучасних умовах глобального техногенного втручання у довкілля набуває актуального значення і дозволяє виявляти, картувати та виконувати прогнозну оцінку закономірностей i динаміки негативних змін екологічного стану грунтових вод [8]. 
Зіставлення в ГІС показників розрахункового часу проникнення забруднюючих речовин крізь зону аерації з переважаючим напрямком фізикохімічної міграції хімічних елементів та існуючим рівнем забруднення дозволяє визначити різний ступінь ризику забруднення грунтових вод та прогнозувати їх підтоплення та забруднення [9].

Система мобільного екологічного моніторингу спрямована на збільшення швидкості обробки аналізів вимірювання і збільшення масштабів дослідження [6]. Система складається 3 переносного комп'ютера (ноутбука), набору периферії: блоку давачів, GPS-антени, GSM-модуля, а також спеціального програмного забезпечення. Система спрямована не на точне визначення параметрів, а працює як якісний показник забруднення території, для встановлення місць, де потрібні лабораторні дослідження. Небезпечними $є$ забруднення поверхневих вод. Вони здатні досить швидко і на великі відстані переносити небезпечні речовини. Робочий діапазон та роздільна здатність обраних сенсорів є цілком придатними для екологічного моніторингу. Спроектована система має у своєму складі давачі для вимірювань органолептичних показників якості води. Основні з них це: окисно-відновний потенціал, кислотність та провідність води, вмісту солей та розчиненого кисню, наявності іонів. За цими показниками є можливою інтегральна оцінка рівня забруднення води у водоймі, придатності води до використання тощо. Почергове підключення давачів до аналогово-цифрового перетворювача, пересилання даних до комп'ютера, калібрація давачів здійснюється за допомогою мікроконтролера - основної частини блоку. GPS-антена підключається до комп'ютера через стандартне розняття. Програмне забезпечення проводить збір та обробку інформації. Отримані дані записуються у базу даних 3 наступною іх візуалізацією на екрані ПК. Використання геоінформаційних систем (ГІС) у поєднанні з картографічними матеріалами дозволяє швидко та оперативно отримувати картину екологічної обстановки на великих територіях. При виникненні техногенної катастрофи особливо важливою є швидкість отримання даних про ㄲï перебіг.

\section{Висновки}

Використання декількох таких систем, що діють у різних місцях, значно підвищує ефективність екологічного моніторингу. GSM-модуль, що входить до складу системи, дає змогу передавати дані до центру спостережень у реальному масштабі часу. Пересилка інформації здійснюється з використанням системи GSM. Окрім локальних баз даних, на мобільних системах створюється також глобальна, яка розміщується в центрі моніторингу. Використання головної бази даних із візуалізованою у вигляді тематичних карт зібраною інформацією дозволяє бачити цілісну екологічну картину. Такий підхід стає незамінним також у разі здійснення операцій з ліквідації стихійних або екологічних лих. 


\section{СПИСОК ЛІТЕРАТУРИ}

1. Триснюк Т.В. Підвищення рівня екологічної безпеки об’єктів природно-заповідного фонду / Т.В. Триснюк, Ю.М. Голован, А.В. Курило // Сучасні інформаційні технології управління екологічною безпекою, природокористуванням, заходами в надзвичайних ситуаціях: Колективна монографія: XVII Міжнародна науково-практична конференція. Інститут телекомунікацій і глобального інформаційного простору НАНУ. Київ. 25-26 вересня 2018 р. - С. 213-214.

2. Trysnyuk, V.M., Shumeiko, V.O., Trysnyuk, T.V., Kurylo, A.V., Golovan, Yu.M. [2020]. Ecological safety of the Carpathian region in the conditions of technogenic dust pollution atmospheric air. Collection of scientific works "Control, navigation and communication systems". Poltava National Technical University named after Yuri Kondratyuk. Issue 1 (59) 2020, P. 127-131.

3. Рудько Г.І., Назаренко М.В. Геоінформаційні технології в надрокористуванні / Г.І. Рудько, М.В. Назаренко - К.: «Академпрес», 2011. - 336 с.

4. Красовський Г.Я., Трофимчук О.М., Крета Д.Л., Клименко В.I., Пономаренко I.Г., Суходубов О.О. Синтез картографічних моделей забруднення земель техногенним пилом з використанням космічних знімків // Екологія і ресурси. - К.: ІПНБ, 2005. №12. - C. 37-55.

5. S. Greben, O. Trofymchuk, V. Trysnyuk, G. Krasovskiy. [2020]. Interpretation of remote sensing data for ecological tasks. IEEE Ukrainian Microwave Week (UkrMW): 10th International Kharkiv Symposium on Physics and Engineering of Microwaves, Millimeter and Submillimeter Waves (21-25 September, Kharkiv, Ukraine), Volume 3, P. 772-776.

6. Trofymchuk, O., Okhariev V., Trysnyuk. V. [2019] Environmental security management of geosystems. Conference Proceedings. 18th International Conference on Geoinformatics Theoretical and Applied Aspects.

7. Триснюк В.М. Екологія Гусятинського району / В.М. Триснюк. - Тернопіль. Тернограф. 2004. - 219 с.

8. Trofymchuk O., Myrontsov M., Okhariev V., Anpilova Y., Trysnyuk V. [2021] Transdisciplinary analytical system for support the environmental researches. Systems, decision and control in energy II. Studies in systems, decision and control. Springer. Cham. 9. Trysnyuk, V., Okhariev, V., Trysnyuk, T., Zorina, O., Kurylo, A., \& Radlowska, C. (2019). Improving the algorithm of satellite images landscape interpretation. In 18th International Conference Geoinformatics - Theoretical and Applied Aspects. (Vol. 2019, pp. 1-5). http://www.earthdoc.org/publication/publicationdetails/?publication=98507

DOI: $10.3997 / 2214-4609.201902084$

Стаття надійшла до редакиії 20.01.2021 і прийнята до друку після рецензування 28.04.2021

\section{REFERENCES}

1. Trysnyuk, T.V., Golovan, Yu.M., \& Kurilo, A.V. (2018). Pidvyshchennya rivnya ekolohichnoyi bezpeky ob'yektiv pryrodno-zapovidnoho fondu [Increasing the level of environmental safety of nature reserves]. In Modern information technologies for environmental safety management, nature management, emergency measures: Collective monograph: XVII International scientific-practical conference (pp. 213-214). Kyiv: Institute of Telecommunications and Global Information Space of NASU (in Ukrainian).

2. Trysnyuk, V., Shumeiko, V., Trysnyuk, T., Kurilo, A., \& Holovan, J. (2020). Ecological safety of the Carpathian region in the conditions of technogenic dust pollution atmospheric air. Control, Navigation and Communication Systems. Academic Journal, 1 (59), 127-131 (in Ukrainian). https://doi.org/https://doi.org/10.26906/SUNZ.2020.1.127 
3. Rudko, G.I, \& Nazarenko, M.V. (2011). Heoinformatsiyni tekhnolohiyi $v$ nadrokorystuvanni [Geoinformation technologies in subsoil use]. Kyiv: "Academpress" (in Ukrainian).

4. Krasovsky, G.Ya., Trofimchuk, O.M., Kreta, D.L., Klimenko, V.I., Ponomarenko, I.G., \& Sukhodubov, O.O. (2005). Syntez kartohrafichnykh modeley zabrudnennya zemel' tekhnohennym pylom z vykorystannyam kosmichnykh znimkiv [Synthesis of cartographic models of land pollution by man-made dust using space images]. Ecology and resources, 12, 37-55 (in Ukrainian).

5. Greben, S., Trofymchuk, O., Trysnyuk, V., \& Krasovskiy, G. (2020). Interpretation of remote sensing data for ecological tasks. In IEEE Ukrainian Microwave Week (UkrMW): 10th International Kharkiv Symposium on Physics and Engineering of Microwaves, Millimeter and Submillimeter Waves (Vol. 3, pp. 772-776). Kharkiv, Ukraine.

6. Trofymchuk, O., Okhariev, V., \& Trysnyuk, V. (2019). Environmental security management of geosystems. In Conference Proceedings. 18th International Conference on Geoinformatics - Theoretical and Applied Aspects.

7. Trysnyuk, V.M. (2004). Ekolohiya Husyatyns'koho rayonu [Ecology of Husiatyn district]. Ternopil: Ternograph (in Ukrainian).

8. Trofymchuk, O., Myrontsov, M., Okhariev, V., Anpilova, Y., \& Trysnyuk, V. (2021). Transdisciplinary analytical system for support the environmental researches. In Systems, decision and control in energy II. Studies in systems, decision and control. Springer, Cham. 9. Trysnyuk, V., Okhariev, V., Trysnyuk, T., Zorina, O., Kurylo, A., \& Radlowska, C. (2019). Improving the algorithm of satellite images landscape interpretation. In 18th International Conference Geoinformatics - Theoretical and Applied Aspects. (Vol. 2019, pp. 1-5). http://www.earthdoc.org/publication/publicationdetails/?publication=98507

DOI: $10.3997 / 2214-4609.201902084$

The article was received 20.01.2021 and was accepted after revision 28.04.2021

\section{Триснюк Тарас Васильович}

кандидат технічних наук, науковий співробітник Інституту телекомунікацій i глобального інформаційного простору НАН України

Адреса робоча: Чоколівський бульвар, 13, Київ, 03186

ORCID ID: 0000-0002-3672-8242, e-mail: taras24t@gmail.com 